\title{
Evaluating the Untapped Potential of U.S. Conservation Investments to Improve Soil and Environmental Health
}

OPEN ACCESS

Edited by:

Patrick Baur,

University of Rhode Island,

United States

Reviewed by:

Manoj Shrivastava,

Indian Agricultural Research Institute

(ICAR), India

Andrea Jilling,

Oklahoma State University,

United States

Cristina Lazcano,

University of California, Davis,

United States

*Correspondence:

Andrea Basche

abasche2@unl.edu

Specialty section:

This article was submitted to Agroecology and Ecosystem Services,

a section of the journal

Frontiers in Sustainable Food Systems

Received: 31 March 2020

Accepted: 26 October 2020

Published: 26 November 2020

Citation:

Basche A, Tully K, Álvarez-Berríos NL,

Reyes J, Lengnick L, Brown T,

Moore JM, Schattman RE,

Johnson LK and Roesch-McNally G

(2020) Evaluating the Untapped

Potential of U.S. Conservation

Investments to Improve Soil and

Environmental Health.

Front. Sustain. Food Syst. 4:547876.

doi: 10.3389/fsufs. 2020.547876

\begin{abstract}
Andrea Basche ${ }^{1 *}$, Katherine Tully ${ }^{2}$, Nora L. Álvarez-Berríos ${ }^{3}$, Julian Reyes ${ }^{4}$, Laura Lengnick $^{5}$, Tabitha Brown ${ }^{6}$, Jennifer M. Moore ${ }^{6}$, Rachel E. Schattman ${ }^{7}$, Lana Koepke Johnson ${ }^{1}$ and Gabrielle Roesch-McNally ${ }^{6}$
\end{abstract}

\begin{abstract}
${ }^{1}$ Department of Agronomy and Horticulture, University of Nebraska-Lincoln, Lincoln, NE, United States, ${ }^{2}$ Department of Plant Science and Landscape Architecture, University of Maryland, College Park, MD, United States, ${ }^{3}$ United States Department of Agriculture Forest Service, International Institute of Tropical Forestry, Río Piedras, PR, United States, ${ }^{4}$ U.S. Department of State, Washington, DC, United States, ${ }^{5}$ Cultivating Resilience, LLC, Asheville, NC, United States, ${ }^{6}$ American Farmland Trust, Washington, DC, United States, ${ }^{7}$ University of Maine School of Food and Agriculture, University of Maine Climate Change Institute, Orono, ME, United States
\end{abstract}

There is increasing enthusiasm around the concept of soil health, and as a result, new public and private initiatives are being developed to increase soil health-related practices on working lands in the United States. In addition, billions of U.S. public dollars are dedicated annually toward soil conservation programs, and yet, it is not well quantified how investment in conservation programs improve soil health and, more broadly, environmental health. The Environmental Quality Incentives Program $(E Q I P)$ is one of the major U.S. public conservation programs administered on privately managed lands for which public data are available. In this research, we developed a multi-dimensional classification system to evaluate over 300 EQIP practices to identify to what extent practices have the potential to improve different aspects of soil and environmental health. Using available descriptions and expert opinion, these practices were evaluated with a classification system based on the practice's potential to exhibit the following environmental health outcomes: (i) principles of soil health to reduce soil disturbance and increase agrobiodiversity; (ii) a transition to ecologically-based management to conserve soil, water, energy and biological resources; and (iii) adaptive strategy to confer agroecosystem resilience. Further, we analyzed nearly $\$ 7$ billion U.S. dollars of financial assistance dedicated to these practices from 2009 through 2018 to explore the potential of these investments to generate environmental health outcomes. We identified nine practices that fit the highest level of potential environmental health outcomes in our classification systems. These included wetlands and agroforestry related practices, demonstrating that ecologically complex practices can provide the broadest benefits to environmental health. Practices with the greatest potential to improve environmental health in our classification system represent 2-27\% of annual EQIP funding between 2009 and 2018. In fiscal year 2018, these practices represented between $\$ 13$ and 121 million, which represented $\sim 0.08 \%$ of total annual USDA expenditures. These classifications and the subsequent funding analysis 
provide evidence that there is tremendous untapped potential for conservation programs to confer greater environmental health in U.S. agriculture. This analysis provides a new framework for assessing conservation investments as a driver for transformative agricultural change.

Keywords: Environmental Quality Incentives Program (EQIP), soil health, agroecology, adaptive capacity, environmental health, resilience

\section{INTRODUCTION}

Soil health has emerged in recent years as a unique and powerful solution to many of the 21st century's most wicked problems: the degradation of natural resources, food security, and climate change. Despite this more recent emergence, soil health is an ancient and ubiquitous agricultural concept. Described in 2,000 year-old Greek and Roman treatises on agricultural productivity (Karlen, 2012), soil health remained a fundamental principle through more than 200 years of modern agricultural philosophical development (Kuepper, 2010). Following the Green Revolutions of the early 20th century, industrialized agricultural systems focused more on external inputs and efficiency while soil health principles were deprioritized (Gliessman, 2014). The growing focus on soil health is a necessary shift in order to address generations of unsustainable agricultural practices in the U.S. that have led to soil degradation through processes such as erosion, salinization, compaction and decreased soil organic matter (Hatfield et al., 2017). The Food and Agriculture Organization of the United Nations estimates that $25 \%$ of the world's agricultural lands are highly degraded (FAO, 2011). Degraded soil resources are increasingly recognized as reducing the capacity of agricultural systems to respond to climate change; and further, improving soil health is a "multi win" approach to generate many valuable social and environmental cobenefits in addition to reducing climate risks (Webb et al., 2017).

Soil health is broadly recognized as the capacity of a soil to function as a vital living ecosystem that sustains plants, animals, and humans (USDA-NRCS, 2020a) although different definitions and conceptualizations of soil health exist, and are evolving (Karlen et al., 2017). Agricultural practices that promote soil health emphasize principles of reduced soil disturbance, increased crop diversity, continuous soil cover and living roots, and the integration of livestock. The intent of these principles are to promote soil health by preventing erosion, increasing soil organic matter, and supporting more resilient agricultural production systems over time. Examples of some common soil health practices include cover cropping, using organic amendments, reducing tillage, and rotating crops (Tully and McAskill, 2020).

As awareness has grown of the many social and ecological benefits associated with implementing soil health building practices, these practices are being promoted by an increasingly diverse chorus of voices. For example, soil health is emerging as an effective natural climate solution (Griscom et al., 2017) that is supported by agribusiness such as Indigo Ag
$(2020)^{1}$, Danone $(2020)^{2}$, and General Mills $(2020)^{3}$, federal policymakers introducing legislation such as the 2019 Climate Stewardship Act (U.S. Congress, 2019) as well as the 2020 Agriculture Resilience Act (U.S. Congress, 2020), and documents such as the USDA's 2020 Agriculture Innovation Agenda (USDA, 2020), and by soil health proponents. All of these stakeholders focus their support on one or more of the many diverse co-benefits of healthy soils, such as improved water quality (Bodell et al., 2019), food quality and human health (Soil Health Institute, 2018), and reduced flood and drought impacts (Basche, 2017). Increasingly, the concept of improving soil health is at the nexus of conversations focused on reducing negative environmental impacts of agriculture, increasing carbon sequestration, and expanding climate resilience.

While there are no federally supported programs with a singular goal of addressing soil and environmental health on working lands, there are a number of programs that address different aspects of conservation, including land retirement programs such as the Conservation Reserve Program (CRP) and working lands programs such as Environmental Quality Incentives Program (EQIP) and Conservation Stewardship Program (CSP) (CRS, 2019). At the core of these programs, there are more than 300 practice standards that guide conservation planning and implementation by Federal and State agencies (USDA-NRCS, 2020b). The Natural Resources Conservation Service (NRCS) of the U.S. Department of Agriculture is responsible for developing and updating conservation practice standards for working and non-working farmlands, ranchlands, and forests. Each conservation practice standard contains information on why, when, and where a specific practice can be implemented, and sets forth the minimum criteria to be met for the practice to achieve its intended purpose. The standards are also evaluated according to their contribution to different program goals, such as soil or water quality improvement, pesticide use reduction, and more recently, greenhouse gas emission reduction and carbon sequestration (USDA-NRCS, 2020c).

The goal of this research is to explore how recent investments in EQIP have the potential to impact soil and environmental health in U.S. working lands through a practice-based assessment

\footnotetext{
${ }^{1}$ Terraton Initiative (2019). Indigo Ag. Available online at: https://www.indigoag. com/the-terraton-initiative (accessed March 24, 2020).

${ }^{2}$ Danone (2020). Regenerative Agriculture. Available online at: https://www. danone.com/impact/planet/regenerative-agriculture.html (accessed March 24, 2020).

${ }^{3}$ General Mills (2019). Regenerative Agriculture Program. Available online at: https://www.generalmills.com/Responsibility/Sustainability/Regenerativeagriculture (accessed March 24, 2020).
} 
that builds upon multiple pre-existing principles. Specifically, we developed outcomes-based classifications that describe the target and potential outcome of practice implementation in the EQIP conservation program. The first of these classifications is based on the ability of a practice to address the principles of soil health, specifically, reducing disturbance or erosion and increasing plant and/or livestock diversity. The second classification is based on agroecological principles articulated by Gliessman (2014), representing the increased potential of the practice to transition an agroecosystem to ecologically-based management, with a goal of conserving soil, water, energy and biological resources. The third classification was based on adaptive strategy criteria following the framework of Walthall et al. (2013), describing the strategy of a practice to change the ecological structure and function of an agroecosystem in response to change. In aggregate, these classifications represent complimentary frameworks for evaluating the potential of U.S. conservation investments to address the increasing interest and demand for improving soil health as well as the environmental co-benefits soil can provide, such as resource conservation, water quality, protecting and improving rural livelihoods, and enhancing adaptation and resilience to the effects of climate change.

This research focuses on the impact of federal investments in soil health and broader environmental health administered by the USDA-NRCS through EQIP. Historically, a major emphasis of the EQIP program has been on livestock and wildlife related practices, which are meant to receive $55 \%$ of overall funding (CRS, 2019; USDA-ERS, 2019). Therefore, we examine the potential for EQIP practices to provide broad co-benefits to soil and environmental health. Specifically in this research, we (1) evaluate all current practices with EQIP through a multidimensional classification system to understand their potential to improve soil and environmental health; (2) quantify the number of federal dollars allocated to these practices between 2009 and 2018. This research critically evaluates how conservation dollars are being spent with respect to soil and environmental health. It is our aim that this and subsequent research can help inform future investment in those practices that provide the broadest benefits.

\section{METHODS}

\section{EQIP Program Data Selection}

Our analysis focused on EQIP for several reasons: First, EQIP is one of the major U.S. public conservation programs administered on private managed lands, and county-level data by conservation practice from the Resource Economics and Analysis Division of the NRCS were readily available. This enabled detailed analysis of the number of acres and dollars allocated to practices that improve soil health and broader environmental health within EQIP. Second, the data on individual and specific conservation practices at the county-level are not available for other conservation programs such as the Conservation Stewardship Program (CSP) or the Conservation Reserve Program (CRP). Finally, we focus on EQIP investments because the number of acres enrolled in EQIP practices that are estimated to improve soil health are several times larger than CRP (USDA-NRCS, 2020d).

\section{Data Acquisition}

Data for all EQIP practices from 2009 to 2018 was acquired by public request from the Strategic Information Team in the Resource Economics and Analysis Division of the Natural Resources Conservation Service (USDA-NRCS, 2020f). Countylevel data were provided for acreage and dollars from years 2009 to 2018 on all available 304 approved conservation practices across all states.

\section{Conservation Practice Outcomes-Based Classifications}

Practice standard information was obtained from the USDANRCS National Conservation Practice Standards catalog to assist in categorizing each practice according to the multi-dimensional outcomes-based classification criteria (described below). This catalog is available online, and describes technical information for the various approved conservation practices (USDA-NRCS, 2020b). State and local NRCS offices select conservation practices from these standards to develop conservation programs that are better suited to local needs. The practice standards are the basic organizing tool for agricultural conservation in the U.S. and are widely used in agricultural conservation program development, planning, and assessment at the local-, state-, and national-level.

We categorized the conservation practices according to criteria specific to each of the following classifications (Figure 1):

1. Practices were categorized by type of practice, indicating the primary asset or land use targeted by the practice, including the following categories (Figure 1A): (1) data monitoring, collection and evaluation; (2) a physical structure or facility or an equipment-related practice; (3) edge of field or boundary practice occurring on the perimeter of a managed land; (4) in-situ practice occurring directly in the managed land; and (5) plan or management description. Facilities included such practices as waste storage facility, compost facility, and sediment basin. Edge-of-field or boundary practices could include ditches or diversions that require soil movement and are utilized on the edge of an agricultural or pasture area. Insitu practices include tillage, cover cropping, alley cropping, etc. that occur within the field or pasture. For our classification system, wetland related practices (creation or restoration, for example) were included in the in-situ category as they are often located on previously cultivated fields, pastures, or forested areas, and therefore represent active management decisions where farmable land is taken out of production in order to optimize use.

2. Practices were then categorized by their soil health outcome on two axes describing whether or not the practice has the potential to reduce erosion and soil disturbance and/or increase agrobiodiversity (plants and/or livestock). In general, this classification was created to incorporate the widely accepted soil health principles from the NRCS (USDANRCS, 2020a). We created a matrix of four quadrants and a binary scheme (yes or no) for the two categories: reducing disturbance or erosion (x axis) and increasing agrobiodiversity (y axis) (Figure 1B). Quadrant 1 represented practices that would not reduce disturbance or erosion nor increase plant or livestock diversity. Quadrant 2 represented practices with 
A
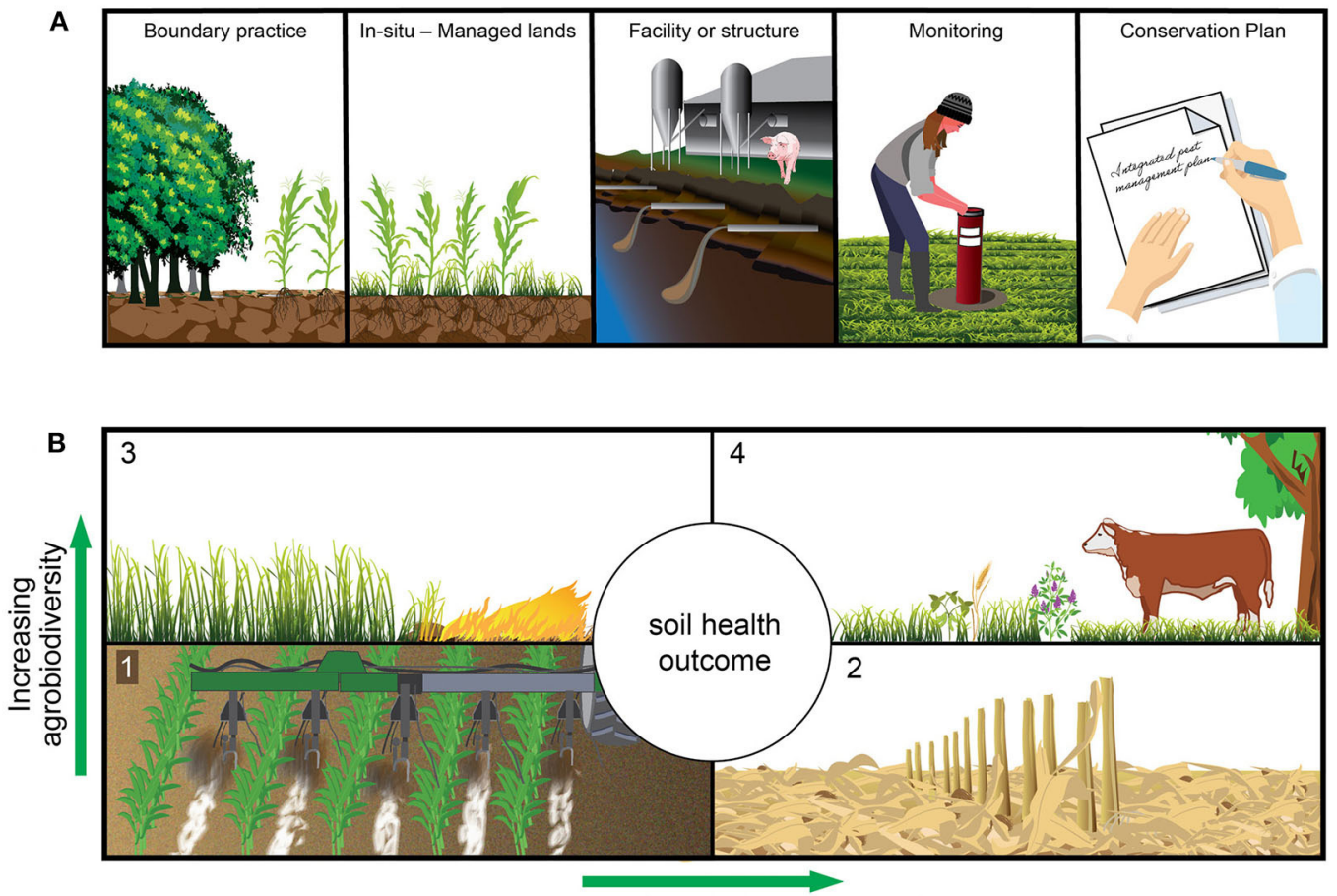

Minimizing soil disturbance or erosion

C

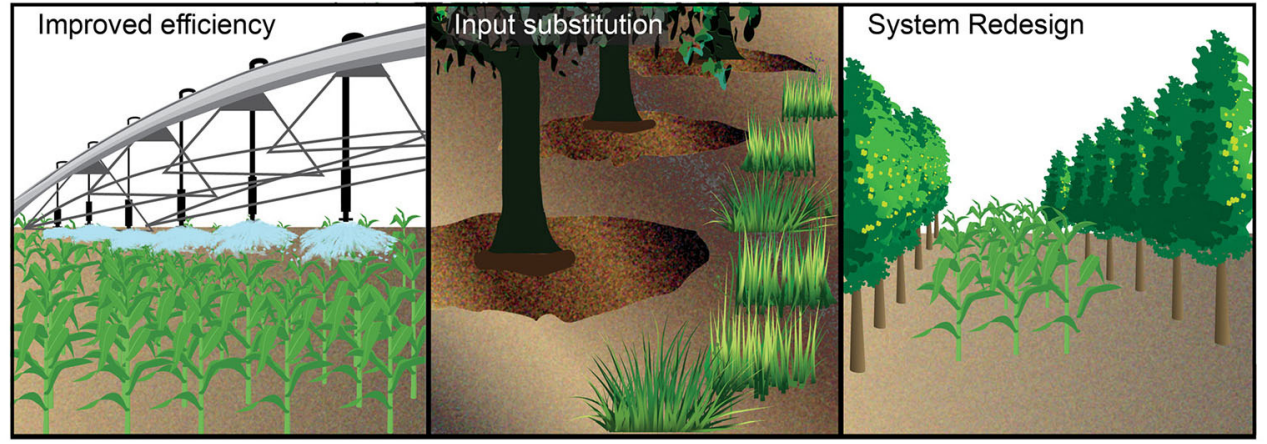

D

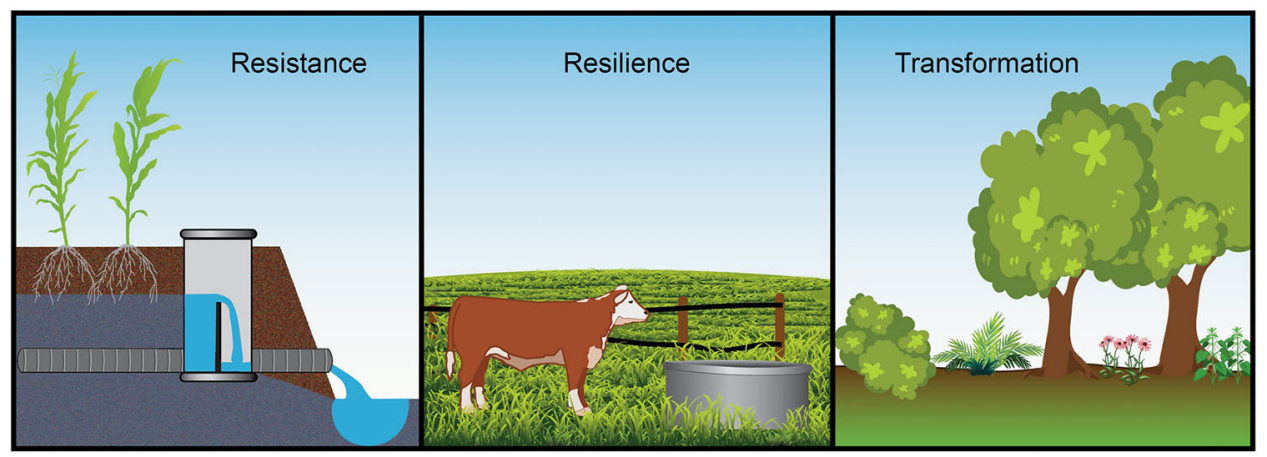

FIGURE 1 | Representations of practices and the various categories included in this analysis. USDA NRCS National Conservation Practice Standards code numbers are included below in parenthesis and can be found at the Standards Catalog Website (USDA-NRCS, 2020b). (A) illustrates the categories within the "type" classification, including: boundary practices, represented by Windbreak/Shelterbelt Establishment (380); managed lands, represented by Cover Crop (340); facility or structure, represented by Waste Storage Facility (313); monitoring, represented by Groundwater Testing (355); and conservation plan, represented by IPM Herbicide Resistance Weed Conservation Plan - Written (154). (B) illustrates the categories within the "soil health outcome" classification, including: Quadrant 1, no change or 
FIGURE 1 | improvement to soil health, represented by Nutrient Management (590); Quadrant 2, reducing soil disturbance or erosion, represented by Residue and Tillage Management, No-Till (329); Quadrant 3, increasing agrobiodiversity, represented by Prescribed Burning (338); and Quadrant 4, both reducing soil disturbance or erosion and increasing agrobiodiversity, represented by Silvopasture (381). (C) illustrates the categories within the transition to ecologically-based management classification, including: Level 1, increasing efficiency, represented by Irrigation Water Management (449); Level 2, input substitution, represented by Mulching (484); and Leve/ 3, system redesign, represented by Alley Cropping (311). (D) illustrates the categories within the adaptive strategy classification, including: Resistance strategies, represented by Drainage Water Management (554); Resilience strategies, represented by Prescribed Grazing (528); and Transformation strategies,

represented by Multi-story Cropping (379).

the potential to reduce disturbance or erosion but not increase plant or livestock diversity. Quadrant 3 represented practices that would not reduce disturbance or erosion, but with the potential to increase plant or livestock diversity. Quadrant 4 represented practices with the potential to both reduce disturbance or erosion and to increase plant or livestock diversity.

Each practice was categorized based on the purpose of the practice as described in the practice standard. Specifically, we focused on those descriptions which were clearly relevant to reducing erosion or enhancing agrobiodiversity. We also considered the conservation practice's physical effects (CPPE) score (USDA-NRCS, 2020c). This is a score created by NRCS on a -5 (detrimental effects) to +5 (positive effects) scale, representing the potential of a practice to either increase or decrease particular environmental effects. We only considered scores for soil erosion impacts (e.g., sheet and rill, wind, ephemeral gully, classic gully) and used the CPPE scores as a guideline to support the final determination of the practice's efficacy in improving soil health. We determine that a practice would not change disturbance or erosion if the score was $=<2$ and it would reduce disturbance and erosion if the score $=>3$. We found that a few practices had the potential to degrade rather than improve soil health and created a category of "negative" to note practices where this was likely to occur.

To validate the soil health outcome classification, we used the categorization of all the practices listed to improve "soil quality" in the 2019 Soil and Water Resources Conservation Act (RCA) report (USDA-NRCS, 2020d) to ensure that these practices were similarly coded as having an effect on soil health. In summary, for this classification we used three sources: expert knowledge, the CPPE scores, and the 2019 RCA report.

3. Practices were also categorized based on their representation of a transition to ecologically-based management, using the principles of agroecology as defined in Gliessman's (2014) framework. This framework describes a continuum of practices in a transition or conversion to more ecologicallybased management, illustrated by their emphasis on principles such as reestablishing "the biological relationships that can occur naturally on the farm instead of reducing and simplifying them" and emphasizing "conservation of soil, water, energy and biological resources" (Gliessman, 2014). Three category levels (i.e., levels of agroecology) were included in this classification: Level 1 refers to practices that are primarily focused on improving efficiency of inputs (i.e., irrigation system improvements, reductions in energy use, waste management), where practice descriptions often included the language "efficiency"; Level 2 refers to practices that are primarily focused on substitution of inputs that are generally understood to be less harmful (i.e., substitute inorganic fertilizer for compost); Level 3 refers to practices that are primarily focused on systemic redesign at the farm-level (i.e., increase agrobiodiversity through hedgerows, intercropping, integrating crops and livestock) (Figure 1C). The ecologically-based management framework and classification levels was used to evaluate investment in sustainable agriculture research by the United States Department of Agriculture (USDA) Research, Extension \& Economics (REE) Mission Area (DeLonge et al., 2016).

4. Finally, we categorized practices using adaptive strategy principles, which consider management strategies along a continuum of change to the ecological structure and function of the agroecosystem (Walthall et al., 2013). Resistance strategies require the least change in agroecosystem form and function and are typically reactive interventions that target specific threats with technological tools, for example the addition of irrigation in areas experiencing more frequent and intense drought or increased use of pesticides in an area experiencing higher pest pressures. Financial tools such as subsidized insurance and disaster relief are also included in Resistance strategies. Resilience strategies change the form and function of the agroecosystem in order to buffer the effects of disturbances and support a rapid return to a healthy condition after a disturbance, with no or minimal management intervention. Resilience strategies are typically proactive interventions that increase the functional and response diversity of the agroecosystem and reduce risks associated with multiple threats. For example, the adoption of soil health practices like cover crops and more diversified crop rotations buffer the effects of more variable rainfall, spread production risk across a variety of crops, reduce year-to-year yield variability, and can enhance profitability (Walthall et al., 2013). Transformation strategies facilitate the transition to a new agroecosystem with substantially different structure and function better suited to sustained production under current or projected conditions. Transformation strategies are typically proactive interventions designed to better position the agroecosystem to sustain production over the long term and reduce risks associated with multiple threats. These strategies also tend to produce multiple benefits to the producer and the local community (Figure 1D). For example, transitioning a conventional row crop operation in a floodplain to a managed grazing operation reduces the risk of flood damage to the operation, enhances regional water quality, and can also reduce the risk of downstream flooding (Basche, 2017). This resistance-resilience-transformation framework 
was recommended for use in an ecosystem-based approach to agricultural adaptation (Easterling, 2009). It has been applied to climate risk management planning in U.S. National Forests (Spies et al., 2010; USDA Forest Service, 2010) and the National Fish, Wildlife, and Plants Climate Adaptation Strategy (NFWPCAP, 2012), and is used to categorize adaptation options in the USDA Climate Hub's Adaptation Workbook (Janowiak et al., 2016).

Where information was limited or not applicable we categorized practices as the following: (1) None: no info was available on the NRCS practice website and the practice name did not provide enough context to categorize; (2) NEI: not enough information from available resources to categorize the practice for a given classification; (3) NA: information was available to suggest that the practice was not applicable to a particular aspect/classification system.

While we recognize how critical the context is under which a practice is implemented, we considered the most optimal potential environmental outcomes, from a soil health, transition to ecologically-based management, and adaptive capacity perspective could occur from in-situ practices occurring directly on managed lands and that fit our highest ranking categories for each classifications (Soil health outcome Quadrant 4; Transition to ecologically-based management Level 3; Adaptive strategy Transformation). The implementation of multiple evaluative frameworks allows us to identify those practices that are most likely to provide numerous co-benefits to soil and the environment health.

A complete version of the classification system and dollars associated with practice codes are available in Supplementary Table 1.

\section{Categorization of Practices}

Based on the expertise of the research team, which was composed of agronomists, soil scientists, ecologists, and social scientists, three team members were selected to lead the classification of the 304 EQIP conservation practices using a coding system that was developed (see full list in section Conservation Practice Outcomes-Based Classifications).

First, $\sim 50 \%$ of practices were categorized independently by three team members. Intercoder agreement was evaluated by comparing the results from the three independent coders. Discrepancies were discussed in detail among the coders and the team. As needed, discrepancies were resolved using appropriate team expertise on USDA-NRCS practice planning and implementation. All practices were then coded two additional times among the experts to ensure consistency of categories among the different outcomes-based classifications.

Of the 304 practices examined, many could not be categorized according to all of the classifications. The full list included 88 "interim" practices, defined as those that are undergoing a 3year trial period (USDA-NRCS, 2007). Based on the time lag of the introduction of these practices, some were duplicative and others no longer have description information available in the online catalog. We were unable to classify these practices because practice standards were not available in the catalog.
Further, we found in our preliminary analysis that the interim practices comprised $<1 \%$ of total funding distributed in the last 5 years, so we decided not to seek the additional information required to classify interim practices in this analysis. Further, detailed standards information was not available for 36 additional practices on the national list provided to us. However, we categorized some of these practices for "type" without more detailed descriptions, because the title of the practice made classification possible. For example, we could categorize some practices if the title included, "plan" or "monitor." As a result, a total of 203 total practices were categorized in the type classification. Following the classification of practice "type," there remained 180 practices that contained descriptions and were coded for the three remaining classifications.

\section{EQIP Program Analysis}

Based on the above classifications and the EQIP data procured via public records request, we determined the distribution of EQIP practices within each classification criteria for their potential to improve soil health, transition to ecologically-based management, and expand adaptive strategy. We also calculated the acres and dollars allocated to different practices at a countylevel over the 10 year period of 2009 to 2018 . The data provided included a column for contract status. We only included "partial certified" and "certified" status contracts because other categories did not have any dollars or acres associated with them. We worked with data based on the "contract year" which would be when the practice payout occurred rather than when the contract was initiated. Data analysis was completed using the R software platform (R Core Team, 2020) as well as ArcGIS (ESRI, 2010) and is summarized as percentages and totals.

\section{RESULTS}

\section{EQIP Spending Overview From 2009 to 2018}

The U.S. Department of Agriculture's budget for 2018 was estimated to be $\$ 144$ billion dollars, with conservation programs administered through the most recent Farm Bill to be $\sim \$ 6.7$ billion (CRS, 2018; USDA, 2019). EQIP is estimated to invest nearly $\$ 2$ billion annually in structural, vegetative and management practices on eligible lands (USDA-NRCS 2020d; CRS 2019) (Figure 2). From this annual investment, between 2009 and 2018, it is estimated that $\sim \$ 9$ billion dollars went specifically to financial assistance supporting practices (USDA-NRCS, 2020d), after subtracting dollars allocated to reimbursables and technical assistance. The contract data provided for the years of 2009-2018 totaled $\$ 6.95$ billion, which represents $\sim 76 \%$ of the total dollars spent for financial assistance in EQIP over this time period. We understand that the data provided to us represents actual dollars spent on practice contracts, whereas other reporting (i.e., USDA-NRCS, 2020d) notes total allocated dollars over a period of time that may not yet have been spent (NRCS Data Team, personal communication).

We first analyzed the database to determine which practices received the most funding overall during this 10 year period. The ten practices receiving the greatest amount of EQIP dollars 


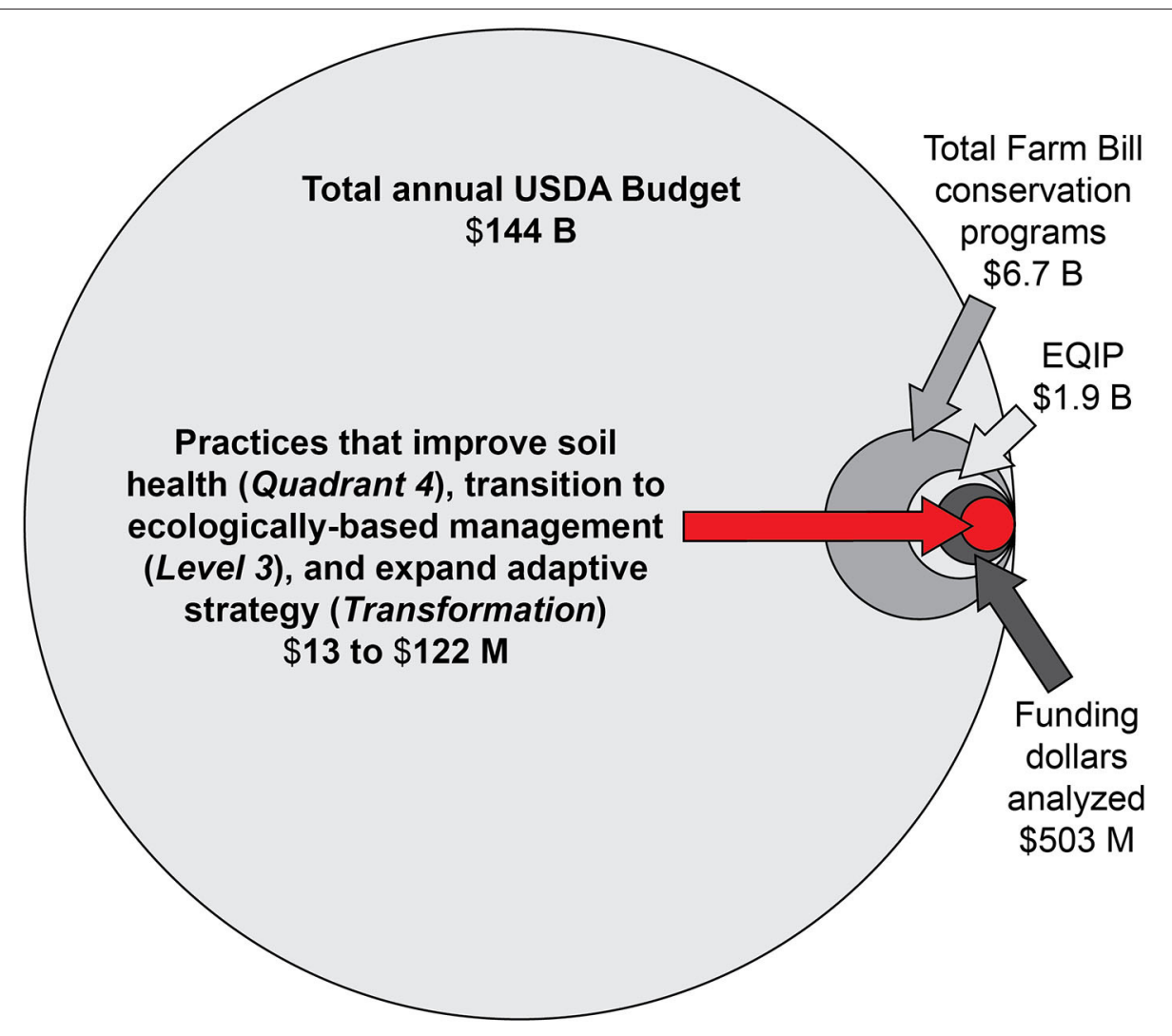

FIGURE 2 | Summary of funding dollars analyzed in this research. We found that investments in conservation practices that improve soil health, transition to ecologically-based management and expand adaptive strategy within EQIP comprise between 13 and 122 million dollars, which represents less than one-tenth of $1 \%$ of the U.S. Department of Agriculture's annual budget which was 144 billion in 2018 (USDA, 2019).

from 2009 to 2018 comprised $\sim 46 \%$ of total spending, and the majority were not in-situ practices occurring on managed lands (Supplementary Table 1); six of the top ten were categorized as facility (Sprinkler System, Waste Storage Facility, Fence, Irrigation System, Irrigation Pipeline, Livestock Pipeline), three were categorized as in-situ practices occurring on managed lands (Cover Crop, Brush Management, Forage and Biomass Planting) and one was categorized as a boundary practice (Heavy Use Area Protection). Only two of the top ten funded practices met our criteria for the top category in any of our classification systems: cover crops and forage and biomass planting (soil health outcome Quadrant 4 and transition to ecologically-based management Level 3). Over this time period, cover crops received $\sim \$ 407$ million ( $6 \%$ of the total dollars analyzed) and forage and biomass planting received $\sim \$ 182$ million (4\% of total dollars analyzed).

\section{EQIP Funding Primarily Focused on Structural, Efficiency and Non-transformative Practices}

In order to understand the potential for EQIP practices to enhance environmental health, specifically to improve soil health, transition to ecologically-based management and expand adaptive strategy, we calculated the dollars allocated to the different categories (Tables 1, 2). Beginning with the type of practice, we found that the largest percent of EQIP dollars were dedicated to the facility category (51\%). In-situ practices occurring on managed lands comprised 39\% of funding while boundary practices comprised $8 \%$. Practices representing plans and/or monitoring systems represented a much smaller percentage of funding, at 2 and $>1 \%$, respectively (Table 1 ).

The soil health outcome classification was created to merge the five widely accepted principles of soil health into four quadrants form an $\mathrm{x}$ and $\mathrm{y}$ axis based on the practice's potential to reduce soil disturbance or minimizing erosion or increase agrobiodiversity (non-crop plants, crops, and livestock) (Figure 1B). We found that $9 \%$ of funding was allocated to practices representing no changes to soil health, or no reductions in soil disturbance, reducing erosion or increasing agrobiodiversity (Quadrant 1) (Table 2). We found that $16 \%$ of funding either minimized soil disturbance, reduced erosion, or increased biodiversity (Quadrants 2 or 3). Further, 22\% of funding went to practices that achieved both goals (Quadrant 4). A small percent of funding went to practices that did not contain enough information to be classified or were determined to have a negative impact on soil health (3 and $2 \%$, respectively). There were four practices that we felt could be categorized as having a negative impact on soil health and included irrigation 
TABLE 1 | Dollars allocated to practices that fell within different categories in the classification of type of practice, describing its targeted land use.

\begin{tabular}{|c|c|c|c|c|c|}
\hline $\begin{array}{l}\text { Target land use } \\
\text { (type classification) }\end{array}$ & $\begin{array}{l}\text { Total payments } \\
2009-2018 \text { (\$\$) }\end{array}$ & $\%$ of total payments & Total acres & \# of practice codes & \# of contracts \\
\hline Overall & 6,948,067,609 & $100 \%$ & $92,621,405$ & 216 & $1,306,410$ \\
\hline Structure or facility & $3,573,944,969$ & $51 \%$ & $6,860,244$ & 76 & 404,616 \\
\hline In situ practice on managed land & $2,686,773,562$ & $39 \%$ & $79,572,871$ & 68 & 688,529 \\
\hline No information & $12,494,687$ & $0.18 \%$ & 293,122 & 13 & 2,738 \\
\hline
\end{tabular}

A full list of practices, total dollars allocated, and categorizations used in this analysis can be found in the Supplementary Material.

TABLE 2 | Dollars allocated to practices that within each of the different classifications and categories included in our analysis.

\begin{tabular}{|c|c|c|c|c|c|c|}
\hline Outcome classification & Category & $\begin{array}{l}\text { Total payments } \\
2009-2018 \text { (\$\$) }\end{array}$ & $\begin{array}{l}\% \text { of total } \\
\text { payments }\end{array}$ & Total acres & $\begin{array}{l}\text { \# of practice } \\
\text { codes }\end{array}$ & $\begin{array}{c}\text { \# of } \\
\text { contracts }\end{array}$ \\
\hline & Overall & $6,948,067,609$ & $100 \%$ & $92,621,405$ & 216 & $1,306,410$ \\
\hline \multirow[t]{8}{*}{ Soil health outcome } & $\begin{array}{l}\text { No change to soil health } \\
\text { (Quadrant 1) }\end{array}$ & $641,491,414$ & $9 \%$ & $16,031,603$ & 11 & 142,661 \\
\hline & $\begin{array}{l}\text { Reduced disturbance or } \\
\text { erosion (Quadrant 2) }\end{array}$ & $1,023,796,334$ & $15 \%$ & $11,263,641$ & 30 & 291,184 \\
\hline & $\begin{array}{l}\text { Increased biodveristy } \\
\text { (Quadrant 3) }\end{array}$ & $63,296,375$ & $1 \%$ & $2,860,570$ & 2 & 35,212 \\
\hline & $\begin{array}{l}\text { Reduced disturbance or } \\
\text { erosion and increased } \\
\text { biodiversity (Quadrant 4) }\end{array}$ & $1,507,645,577$ & $22 \%$ & $51,555,717$ & 40 & 384,951 \\
\hline & Negative impact & $113,633,641$ & $2 \%$ & 618,546 & 4 & 12,535 \\
\hline & Not enough information & $53,302,645$ & $1 \%$ & 10,508 & 1 & 6,101 \\
\hline & No information & $107,469,290$ & $2 \%$ & 469,176 & 36 & 34,914 \\
\hline & Not applicable to category & $3,437,432,333$ & $49 \%$ & $9,641,907$ & 92 & 398,852 \\
\hline \multirow{6}{*}{$\begin{array}{l}\text { Transition to ecologically-based } \\
\text { management }\end{array}$} & Improved efficiency (Level 1) & $3,495,166,193$ & $50 \%$ & $26,197,115$ & 82 & 494,933 \\
\hline & Input substitution (Level 2) & $264,395,194$ & $4 \%$ & $12,896,714$ & 12 & 80,084 \\
\hline & System redesign (Level 3) & $1,609,928,569$ & $23 \%$ & $48,109,916$ & 43 & 420,217 \\
\hline & Not enough information & $509,552,978$ & $7 \%$ & $3,041,311$ & 4 & 148,431 \\
\hline & No information & $107,469,290$ & $2 \%$ & 469,176 & 36 & 34,914 \\
\hline & Not applicable to category & $961,555,384$ & $14 \%$ & $1,737,435$ & 39 & 127,831 \\
\hline \multirow[t]{4}{*}{ Adaptive strategy } & Resistance & $5,320,989,959$ & $77 \%$ & $36,211,210$ & 138 & 859,540 \\
\hline & Resilience & $1,378,187,989$ & $20 \%$ & $54,568,715$ & 30 & 375,759 \\
\hline & Transformation & $141,420,370$ & $2 \%$ & $1,372,304$ & 12 & 36,197 \\
\hline & No information & $107,469,290$ & $2 \%$ & 469,176 & 36 & 34,914 \\
\hline
\end{tabular}

A full list of practices, total dollars allocated, and categorizations used in this analysis can be found in the Supplementary Material.

land leveling, land smoothing, land clearing and grazing land mechanical treatment. We found that about half, or $49 \%$ funding in the program, were not directly applicable to any of the soil health outcomes in this classification system.

In terms of the various practices representing a transition to ecologically-based management, we found that $50 \%$ of funding went to the Level 1 category, representing practices that are aimed toward efficiency improvements (Table 2). We found that $4 \%$ of funding went to practices that could be classified as Level 2 (e.g., input substitution) and 23\% were classified as Level 3 (e.g., system redesign). The remaining funding $(23 \%)$ went to practices that either did not contain enough information to code in this classification, or were not applicable.

The adaptive strategy framework classifies practices according to successively greater change in the form and function of an agroecosystem in order to increase adaptive capacity (Walthall et al., 2013). The majority of funding went to practices in the Resistance category (77\%) or those that avoid altering the existing structure and function of the production system, while $20 \%$ of funding went to practices classified under the Resilience class category (e.g., moderate adjustments to the structure and function of the existing production system to enhance functional 


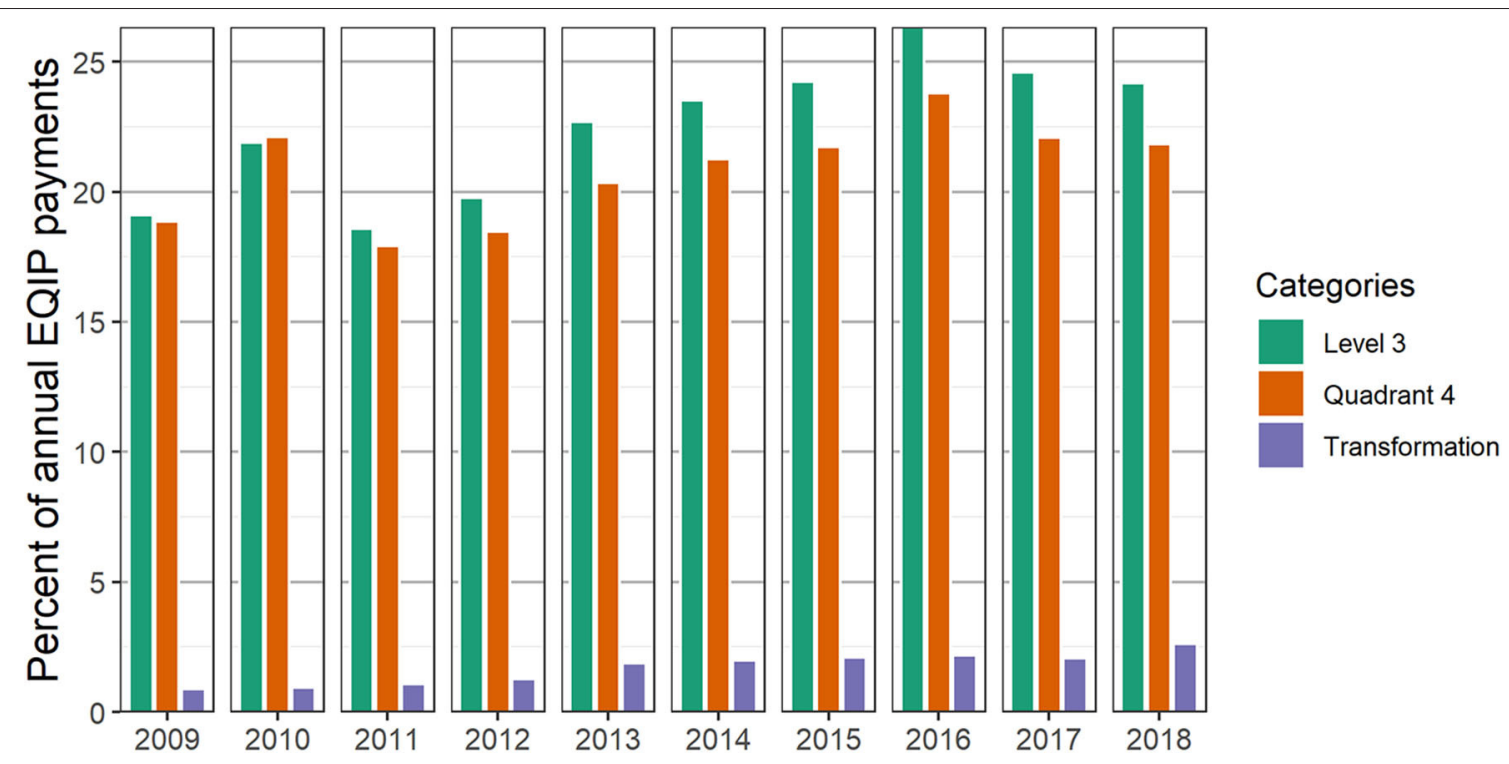

FIGURE 3 | Annual percent of total EQIP conservation practice investments from 2009 to 2018 dedicated to practices that were categorized as having the greatest potential to improve soil health (green), transition to ecologically-based management (orange), and expand adaptive strategy that were also executed in-situ on managed lands (purple). Total investments analyzed annually represented between \$503 million (2018) up to \$792 million (2013) (Supplementary Table 2). Over this time period, Level 3 investments ranged from 19 to $26 \%$, Quadrant 4 investments ranged from 18 to $24 \%$, and Transformation investments ranged from 1 to $3 \%$ (Supplementary Table 2).

and response diversity) (Table 2 ). We found that $\sim 2 \%$ of funding went to practices categorized as Transformation (e.g., major changes to the structure and function of the existing production system to enhance functional and response diversity) and another $2 \%$ did not contain enough information to categorize in this classification.

Investment in practices with the greatest potential to improve soil health outcomes (Quadrant 4, minimizing erosion and disturbance, maximizing biodiversity) and representing a transition to ecologically-based management (Level 3, system redesign) have fluctuated between $\sim 17-27 \%$ of total spending from 2009 to 2018 (Figure 3). In general, these practices increased from 2008 to 2010, decreased in 2011 and then increased again until 2016; however they have declined in the most recent years. Investment in the most optimal adaptive strategy practices (Transformation) have increased slightly over the last 10 years, but were never more than $\sim 3 \%$ of EQIP expenditures analyzed (Figure 3). The recent decline in Level 3 and Quadrant 4 funding may be partially explained by an increase in funding for the Conservation Stewardship Program (USDA-NRCS, 2020e), and potentially reflect farmer enrollment in different conservation programs.

Our analysis suggests that practices with the most potential to improve soil health, transition to ecologically-based management, and expand adaptive strategy executed in-situ on managed lands received $\sim 2-27 \%$ of EQIP funding, depending on the year (Figure 3). In fiscal year 2018, the total dollars spent on these practices was $\$ 13$ million (Transformation), $\$ 110$ million (Quadrant 4), and \$121 million (Level 3), which represents at most $0.08 \%$ of the total $\$ 144$ billion USDA annual budget (Figure 2).

\section{Classification Systems Identify Overlapping, Complex Practices With the Largest Potential for Improving Environmental Health}

Through our multi-dimensional classification system, we found a total of nine practices that fit categories with the greatest potential to improve environmental health (soil health outcome Quadrant 4, minimizing soil disturbance or erosion and increasing agrobiodiversity and; transition to ecologically based management, Level 3; Adaptive strategy Transformation) that were also executed in-situ on managed lands (Figure 4). These represent diversified crop, livestock, and forestry management including silvopasture and other agroforestry practices, wetland creation and restoration, and wildlife habitat management. The overlap of certain practices in all top categories demonstrate that our classification systems valued ecologically-complex practices that enhance biological diversification.

There was particularly high overlap in practices executed in-situ that were also categorized as both soil health outcome Quadrant 4 and transition to ecologically-based management Level 3, where 28 of the 29 and 30 practices were the same, respectively (Figure 4). Some of the practices that comprised the largest percentages of funding within both of those categories included cover crops, forage and biomass planting, forest stand improvement, prescribed grazing, and watering facility (Table 3). For practices categorized as Transformation, 


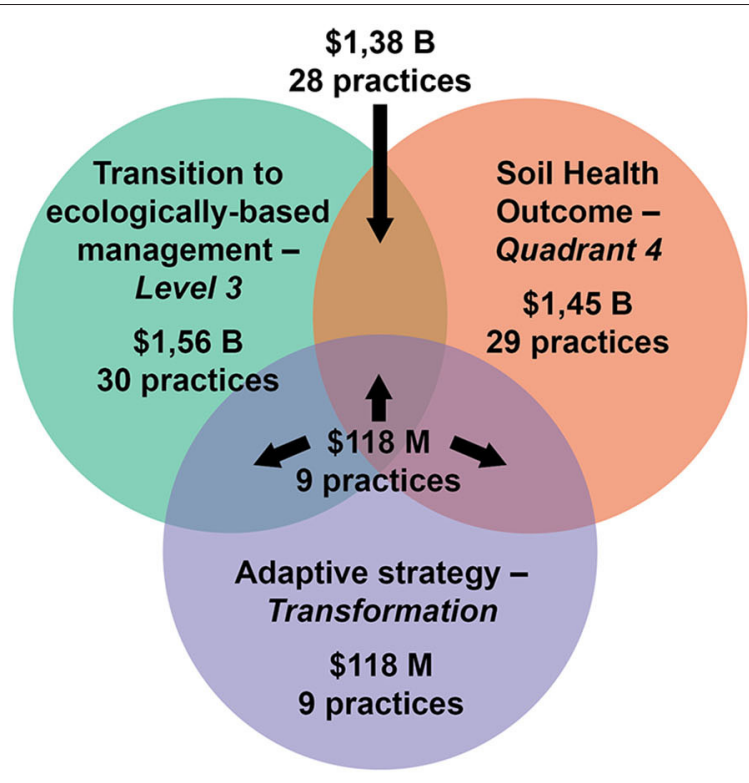

\section{In-situ practices categorized to have the greatest potential to improve environmental health}

1. Alley Cropping

2. Multi-Story Cropping

3. Silvopasture Establishment

4. Tree/Shrub Establishment

5. Wetland Wildlife Habitat Management

6. Constructed Wetland

7. Wetland Restoration

8. Wetland Creation

9. Wetland Enhancement

FIGURE 4 | Total invested dollars in the EQIP program from 2009 to 2018 in the classifications and categories having the greatest potential to improve soil health (green), transition to ecologically-based management (orange), and expand adaptive strategy (purple) that were also executed in-situ on managed lands. Overlapping practices meeting multiple top categories and invested dollars are identified in the Venn diagram. Our analysis identified nine overlapping in-situ practices on managed lands in the top categories for our classifications.

funding was dominated by tree/shrub establishment (insitu) with a lesser amount dedicated to windbreak/shelterbelt establishment (boundary practice). A full list of practices, associated classifications, and total funding levels for the last 10 years can be found in Supplementary Table 1.

\section{Top Practices Are Clustered Geographically}

We evaluated the distribution of EQIP funds geographically to understand if there were regions where a greater percentage of the program dollars were dedicated to the most optimal practices (Figure 5). Regions with a greater percent of support for most optimal practices in soil health outcomes and ecological intensification were similar; we found regional clusters of high percentages $(>40 \%)$ in the eastern Corn Belt, Northern and Southern Great Plains, as well as parts of the mid-Atlantic, Gulf Coast, Pacific Northwest, Alaska and Puerto Rico. In general, we found lower percentages (0-20\%) of funding allocated for these practices in the Mid-Atlantic and Mountain West regions. In contrast, optimal transformation practices were funded at lower levels $(0-20 \%)$ in West coast states, the Northeast, Great Lakes, Gulf Coast, Great Plains and Mountain West as well as Alaska, Hawaii and Puerto. In only a few scattered locations across the US did funding levels for these practices reach $>40 \%$.

\section{Cover Crops Dominate Acreage for Conservation Spending on Optimal Practices}

We investigated how EQIP acreage had shifted over the last 10 years for select practices that we considered to have the largest potential to improve environmental health. We focused on cover crops, forage and biomass planting and tree/shrub establishment which represented large percentages of investments across categories in our classification systems (section Classification Systems Identify Overlapping, Complex Practices With the Largest Potential for Improving Environmental Health) and were practices that were also consistently reported in acres. From 2009 to 2018 we analyzed funding representing $\sim 92.6$ million acres of cropland (Table 1). Cover crops represented the largest number of acres of these three practices, then forage and biomass planting followed by tree/shrub establishment (Figure 6). Cover crop acreage supported by EQIP reached a maximum of $\sim 1.8$ million acres in 2016; both forage and biomass planting and tree/shrub establishment were consistently under 250,000 acres combined. For context, there are $\sim 320$ million harvested cropland acres in the U.S. (USDA-NASS, 2020). Although limited data exists to track national use of conservation practices, the 2017 Census of Agriculture estimated that there were $\sim 15$ million acres of cover crops on U.S. cropland (USDA-NASS, 2020); by these estimates EQIP cover crop contracts would represent $\sim 10 \%$ of all cover crops utilized nationally.

\section{DISCUSSION}

\section{Reprioritizing Conservation Investments to Generate Greater Soil and Environmental Health}

In this research, we utilized a multi-dimensional classification system to evaluate conservation practices for their potential to improve soil health, transition to ecologically-based 


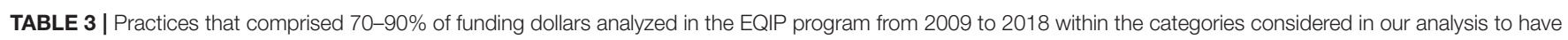
the greatest potential to improve environmental health.

\begin{tabular}{|c|c|c|c|c|c|c|}
\hline $\begin{array}{l}\text { Outcome classification and } \\
\text { category }\end{array}$ & Practice name & $\begin{array}{l}\text { Total payments } \\
2009-2018 \text { (\$\$) }\end{array}$ & $\begin{array}{l}\% \text { of payments } \\
\text { within Category }\end{array}$ & $\begin{array}{l}\text { Target land use } \\
\text { (type } \\
\text { classification) }\end{array}$ & $\begin{array}{l}\text { NRCS practice } \\
\text { code }\end{array}$ & $\begin{array}{l}\text { \# of practice } \\
\text { codes }\end{array}$ \\
\hline & Overall & $6,948,067,609$ & $100 \%$ & & - & 216 \\
\hline \multirow{7}{*}{$\begin{array}{l}\text { Soil health outcome: Reduced } \\
\text { disturbance or erosion and increased } \\
\text { biodiversity (Quadrant 4) }\end{array}$} & Quadrant 4 total$^{*}$ & $1,507,645,577$ & - & & - & 40 \\
\hline & Cover Crop & $406,855,053$ & $27 \%$ & in-situ practice & 340 & - \\
\hline & $\begin{array}{l}\text { Forage and Biomass } \\
\text { Planting }\end{array}$ & $192,483,749$ & $13 \%$ & in-situ practice & 512 & - \\
\hline & Forest Stand Improvement & $166,560,468$ & $11 \%$ & in-situ practice & 666 & - \\
\hline & Prescribed Grazing & $115,964,156$ & $8 \%$ & in-situ practice & 528 & - \\
\hline & Tree/Shrub Establishment & $107,485,940$ & $7 \%$ & in-situ practice & 600 & - \\
\hline & Terrace & $94,930,987$ & $6 \%$ & in-situ practice & 612 & - \\
\hline \multirow[t]{7}{*}{$\begin{array}{l}\text { Transition to ecologically-based } \\
\text { management (Level 3) }\end{array}$} & $\begin{array}{l}\text { System redesign (Level 3) } \\
\text { total }^{\star}\end{array}$ & $1,609,928,569$ & - & & - & 43 \\
\hline & Cover Crop & $406,855,053$ & $25 \%$ & in-situ practice & 340 & - \\
\hline & $\begin{array}{l}\text { Forage and Biomass } \\
\text { Planting }\end{array}$ & $192,483,749$ & $12 \%$ & in-situ practice & 512 & - \\
\hline & Forest Stand Improvement & $166,560,468$ & $10 \%$ & in-situ practice & 666 & - \\
\hline & Watering Facility & $150,427,064$ & $9 \%$ & in-situ practice & 614 & - \\
\hline & Prescribed Grazing & $115,964,156$ & $7 \%$ & in-situ practice & 528 & - \\
\hline & Tree/Shrub Establishment & $107,485,940$ & $7 \%$ & in-situ practice & 612 & - \\
\hline \multirow[t]{7}{*}{ Adaptive strategy (Transformation) } & Transformation total* & $141,420,370$ & - & & - & 12 \\
\hline & Tree/Shrub Establishment & $107,485,940$ & $76 \%$ & in-situ practice & 612 & - \\
\hline & $\begin{array}{l}\text { Windbreak/Shelterbelt } \\
\text { Establishment }\end{array}$ & $13,363,897$ & $9 \%$ & boundary practice & 380 & - \\
\hline & $\begin{array}{l}\text { Windbreak/Shelterbelt } \\
\text { Renovation }\end{array}$ & $9,539,717$ & $7 \%$ & boundary practice & 650 & - \\
\hline & $\begin{array}{l}\text { Wetland Wildlife Habitat } \\
\text { Management }\end{array}$ & $6,032,925$ & $4 \%$ & in-situ practice & 644 & - \\
\hline & Wetland Restoration & $1,459,018$ & $1 \%$ & in-situ practice & 657 & - \\
\hline & Silvopasture Establishment & $1,176,973$ & $1 \%$ & in-situ practice & 381 & - \\
\hline
\end{tabular}

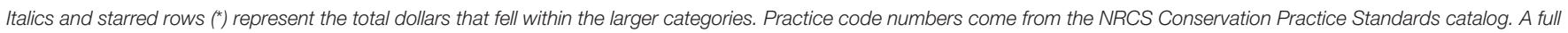
list of practices, total dollars allocated, and categorizations used in this analysis can be found in Supplementary Table 1.

management, and expand adaptive capacity. Given increasing interest and public investments being dedicated to soil health and related environmental and social outcomes, we argue that there is a need to consider multiple criteria that can address potential co-benefits and scale of outcomes of such investments. Evaluating these practices through different classifications sheds light on those practices are most likely to provide a suite of environmental benefits. The growing interest in improving soil health recognizes these links as an opportunity to also improve environmental health by increasing water quality, enhance wildlife habitat, reduce greenhouse gas emissions, increase resilience to climate change, and sequester carbon (Griscom et al., 2017; Harrigan and Charney, 2019; Zimnicki et al., 2020).

Using different classifications to evaluate the practices allowed us to identify those with the highest potential to generate co-benefits. In our analysis, we found that these represent less than one-third of EQIP dollars on an annual basis, and overall a small fraction of USDA dollars allocated annually over the last decade. This is similar to a recent USDA-NRCS report which categorized $\sim 25 \%$ of acres enrolled in EQIP as "soil health practices" (USDA-NRCS, 2020d). We suggest that policymakers prioritize funding and outreach efforts to promote this set of optimal practices where applicable in order to increase return on public investment in conservation incentives. This finding echoes a recent Governmental Accountability Office (GAO) report indicating that EQIP could be better optimized to produce environmental outcomes (GAO, 2017). Specifically the GAO (2017) recommends that the USDA "modify guidance and ranking tools so that they more accurately value an EQIP application's anticipated environmental benefits relative to estimated costs." Our evaluation addresses this explicit recommendation, and by doing so identifies a few dozen practices (Supplementary Table 1) that could be promoted for their ability to generate a diversity of environmental and social benefits on managed lands, including enhancement of soil health, transitioning to more ecologicallybased management and enhancing the adaptive capacity of agroecosystems. 


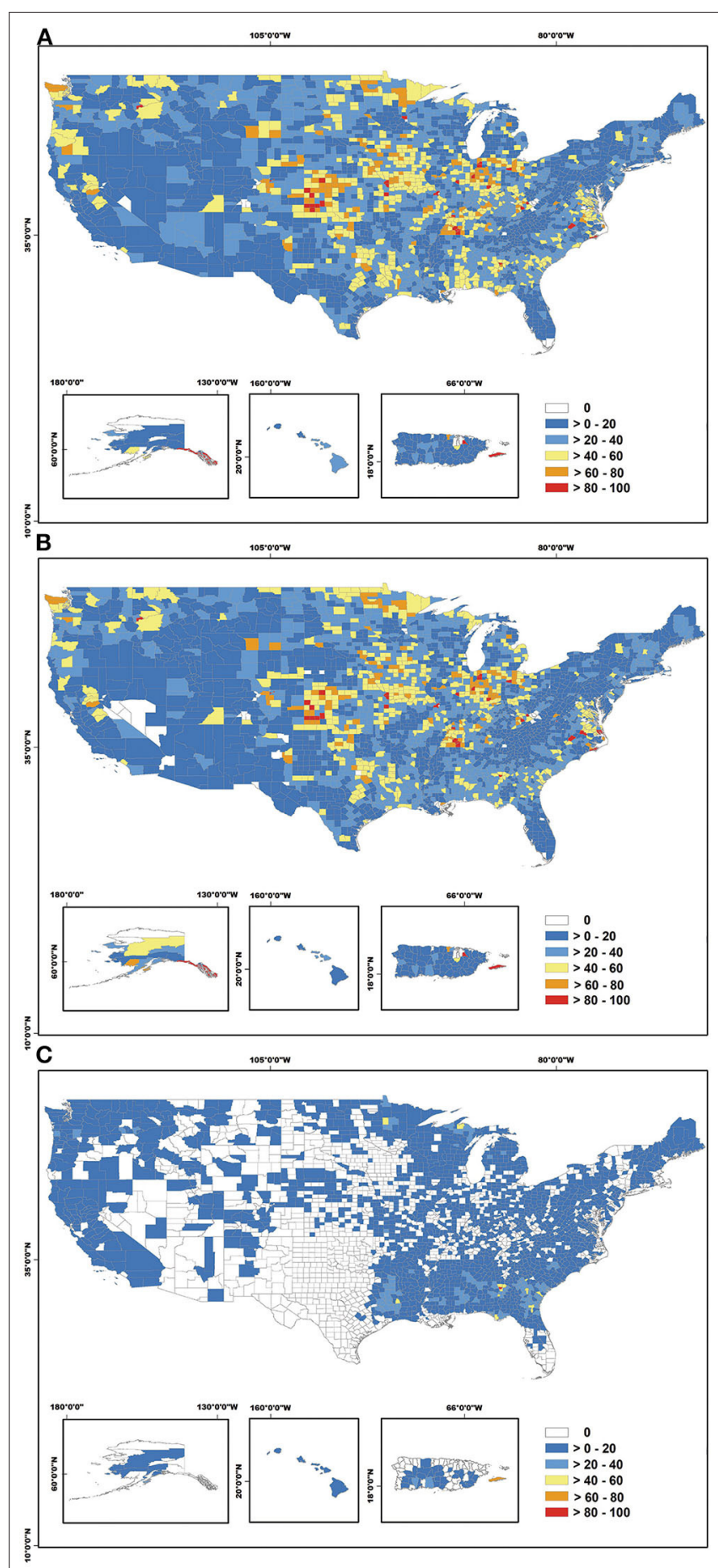

FIGURE 5 | Choropleth maps representing the percentage of total EQIP investments from 2009 to 2018 dedicated to practices that were categorized as having the greatest potential to improve soil health, transition to ecologically-based management, and expand adaptive strategy that were also executed in-situ on managed lands. (A) depicts the percent of total EQIP investments dedicated to Leve/ 3 , (B) depicts the percent of total EQIP investments dedicated to Quadrant 4, and (C) depicts the percent of total EQIP investments dedicated to Transformation practices.
This multi-dimensional classification system could be useful to the assessment of other existing agricultural conservation programs and could also inform strategic implementation of new public and private conservation initiatives. These frameworks can contribute to more informed discussions about the intent and effect of conservation investments. Future iterations of this approach could be applied to other conservation programs, such as CRP and CSP, provided comparable practice implementation data and practice descriptions become available.

We recognize that conservation can be a complicating factor to agronomic management, which is often cited by producers innovating with cover crops as a barrier to their wider use (Roesch-McNally et al., 2018). However, we argue that in most cases, conservation practices may also be viewed as having a positive impact on production. We reject the idea that practices must be an "either or" scenario and that production and profitability benefits do accrue from the outcomes-based practices outlined in this analysis, including examples such as increasing infiltration with more perenniallybased agroecosystems (Basche and DeLonge, 2019), converting unprofitable land to an alternative use with perennial crops (Brandes et al., 2016), and improving weed suppression, productivity and yield stability with diverse crop rotations (Davis et al., 2012; Monast et al., 2018; Weisberger et al., 2019; Bowles et al., 2020).

\section{Enhancing the Adaptive Capacity of Agriculture Through Transformational Change}

Our analysis suggests that conservation practices that promote soil health by reducing disturbance and increasing biodiversity (Quadrant 4) and that those that fall into the system redesign agroecology level categories (Level 3) are the same practices that promote Transformative adaptation in agriculture in the adaptive strategy classification. The overlapping benefits described in all of the classifications underpin how transformational changes in agriculture can support better management of ongoing and future climate risks. The ability of a farm to respond to challenges or take advantage of opportunities related to climate risk occurs within an operating context consisting of the limits imposed by local ecological, social and economic realities (Walthall et al., 2013; Lengnick, 2014). The multi-dimensional classification system recognizes that expanding this operating context through increasing biodiversity, improving soil health and recoupling biological cycles creates more resilience in changing climate (Kates et al., 2012; Webb et al., 2017). It is important to recognize that productivity gains in agriculture achieved over the last several decades have occurred within a relatively stable climate period that we cannot expect to continue (Hatfield et al., 2014). While much of these productivity gains have been achieved through a focus on incremental improvements that might be described as efficiency or resistance approaches, increasingly, shifting to an emphasis on natural resource conservation, biological diversification and soil health to adapt to climate 


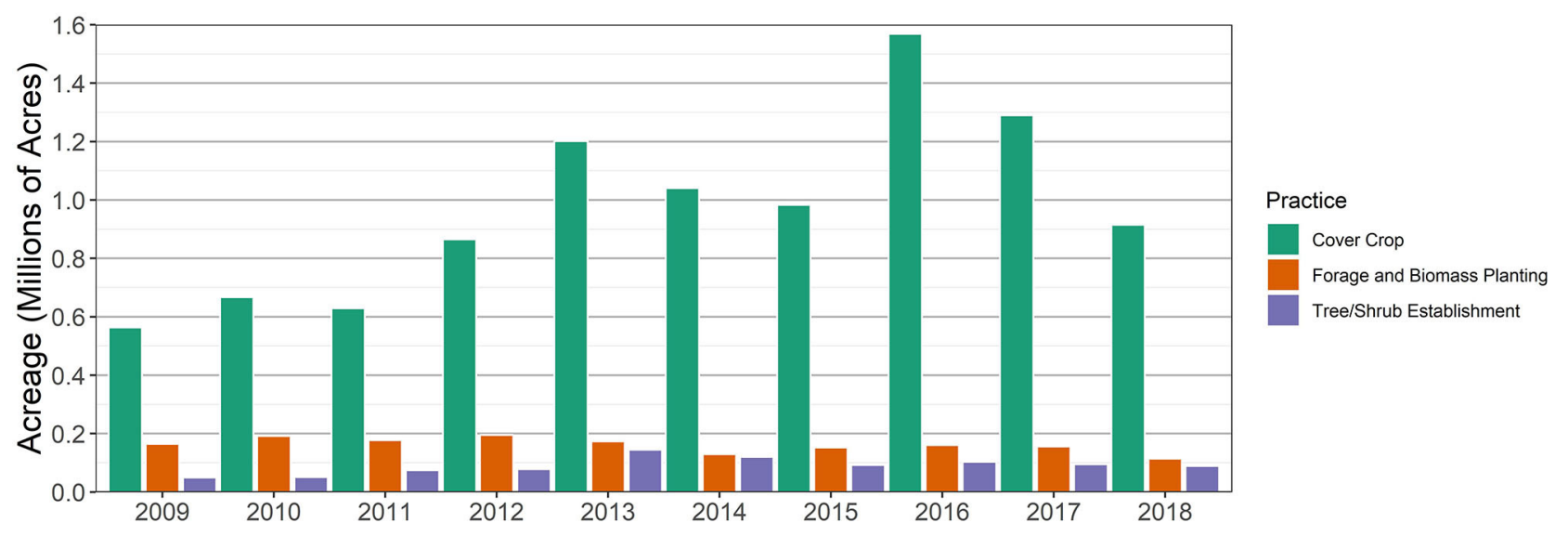

FIGURE 6 | EQIP acreage dedicated to cover crops (green; 340), forage and biomass planting (orange; 512), and tree/shrub establishment (purple; 612) from 2009 to 2018. We focused on these practices because they represented larger percentages of investments dedicated to top categories in our classification system (section Classification Systems Identify Overlapping, Complex Practices With the Largest Potential for Improving Environmental Health, Table 3) and were consistently reported in acres.

change is recognized by national and international assessments as a critical adaptation strategy (Janowiak et al., 2016; FAO, 2018; Gowda et al., 2018; HLPE, 2019). This shifting emphasis recognizes that transformative, ecologically-based strategies can improve ecosystem function; for example, improving soil health in order to reestablish biological relationships that occur naturally on the farm rather than simplifying them (such as water and/or nutrient cycling as well as pest management), can lead to increased profitability and productivity (LaCanne and Lundgren, 2018; Rosenzweig et al., 2018a,b). Overall, the practices highlighted recognize the multitude of co-benefits afforded by select conservation programs with opportunity to improve multiple aspects of environmental health.

Our analysis found that conservation investments made through the EQIP program are dominated by practices that promote input efficiencies (Level 1) and resistance strategies (those that increase adaptive capacity without change to structure and function of the existing agroecosystem). Soil health investments were about evenly divided between investments that promote changes in physical (Quadrants 1 or 2) vs. biological aspects of soil health (Quadrants 3 or 4). Considered together, EQIP investments are dominated by practices that promote incremental adaptation and offer limited support for conversion to ecologically-based management, or Transformative adaptations. While incremental adaptation has contributed to the persistence of agricultural production systems over time and through changing environmental and social conditions, and an overemphasis on incremental adaptation can promote maladaptation (Kates et al., 2012; Janowiak et al., 2016) and lead into an adaptation trap (Walthall et al., 2013).

There were differences in how cover crops were classified amongst our top categories, which impacted the range of results given that cover crops are one of the top ten EQIP funded practices. Although Gliessman (2014) considers cover crops a Level 2 practice, in our expertise, we see that many innovative cover crop producers are utilizing the practice as an approach to diversify farms and reduce reliance on inputs, which we believe represents the description more of a Level 3 than Level 2 practice. In fact, innovative producers often describe their management system with cover crops as a "whole-system" (Basche and RoeschMcNally, 2017). We did not, however, believe that cover crops represent a Transformation practice where they fundamentally alter the structure and function of an agroecosystem.

\section{Limitations of the Framework and Available Data}

There were a few limitations to our analysis and ability to categorize practices, including the context under which practices are implemented as well as availability of detailed practice information. As a research team, we recognized that context is critical for making many important determinations of the impact of agricultural management including conservation. Where possible, we did our best to assume the most positive possible outcome of a practice and inferred context from the information available in the USDA-NRCS conservation practice descriptions. That is, some practices may indirectly impact soil health, but could be combined with other practices ("stacked") to provide a direct impact on soil health especially if implemented in a particular way (Tully and McAskill, 2020). For example, a fence alone does not directly impact soil health, but when used in combination with rotational grazing, could improve soil health outcomes. As we evaluated each practice individually, we did not have information of additional context for how it was implemented or combined with other practices. Future efforts could include looking more strategically at USDA-NRCS conservation plans or contract data, as they offer insights on how conservation practices evolve and are stacked when implemented on the farm. We recognize that it is critical to consider how practices might be utilized together or stacked to provide environmental benefits 
both on- and off-farm, however it is difficult to impossible to acquire comprehensive conservation practice data at a national scale. This would better match how producers implement and evolve conservation practices on their operations. Furthermore, quantifying the benefits from stacking practices at different scales will help improve soil health more holistically. As a result, we recognize that our estimates of dollars spent to achieve particular outcomes are not all encompassing and do not include as explicit a focus on some of the environmental co-benefits (reducing greenhouse gas emissions from agriculture, for example).

We do not discount the value of certain ex-situ (practices not conducted directly on the managed land) efforts that could positively address soil health (e.g., a conservation plan designed to address soil health resource concerns). However, the goal of this analysis was to focus on investments with the most direct and greatest potential to improve environmental health, and therefore would argue that ex-situ practices have an indirect rather than direct impact.

Finally, during the process of this work we found that many practice descriptions were simply unavailable or did not contain enough information to be able to classify into all of our categories. We could not find comprehensive information online for the interim practices (88 practices), and there were another 36 practices that were listed in our public data request but descriptions were not available. Although, we did consult state standards documents that were provided to us to see if information on practices was available there rather than the national catalog. However, we ultimately decided that if practice descriptions were not available through the National Standards catalog, we would not include them in the analysis, in order to create an analysis that was more national in scope. Our understanding is that the National Standards catalog is updated annually, and we would encourage comprehensive, publicly-available information continue to be made available about practices within the conservation programs.

\section{Future Research and Conservation Program Implementation}

Future research could utilize this framework in combination with a "hotspot" analysis to detect if specific conservation practices are geographically clustered or co-located. Such spatial analyses could further determine if practices are "stacked" and provide more context for soil and environmental health outcomes, as well as understanding of facilitators of wider practice use. Interest in implementing climate solutions has increased at a federal level and recent reports and legislation such as the 2020 Senate Climate Crisis Report, the Senate's Growing Climate Solutions Act of 2020, the 2020 House of Representatives Agriculture Resilience Act highlight a critical need for policy-makers to identify practices that offer climate change mitigation and adaptation co-benefits. Our framework, which includes classifications for soil health, environmental health and resilience, could be implemented to identify practices with co-benefits to support future program development.
Further, the framework could be used at a state- or even international-level for evaluating conservation programs. For example, states such as Maryland, which have a recent history with implementing large conservation programs to address resource concerns, could utilize such a framework to identify those practices most effective at meeting program goals. Overall, this framework has potential to serve as a useful tool for new development of policies, and could further be utilized to shift or reprioritize current programs. This framework offers researchers and policy-makers a useful new tool to reevaluate the long-standing emphasis in U.S. agriculture on technological risk management strategies to develop policies and programs designed to capture the benefits of ecosystem-based solutions that afford climate resilience to farms, communities and the planet.

\section{CONCLUSIONS}

There is a need to critically evaluate how conservation dollars are being spent, particularly with the potential of increased investments in the future given expanded interest in negating environmental impacts from agriculture. We used a multi-dimensional classification system to evaluate the potential for conservation practices and funding within EQIP to improve soil health, transition to ecologically-based management, and expand adaptive strategy. From 2009 to 2018, we found that there was limited investment in those practices that have the greatest potential to improve these aspects of environmental health, representing $\sim 2-27 \%$ of the program's expenditures, or less than one-tenth of $1 \%$ of USDA's annual budget (\$13-121 million out of $\$ 144$ billion in 2018). This multi-dimensional approach allowed us to determine where classifications converged and identify those practices that have the potential to achieve multiple improvements in soil and environmental health, including $\sim 28$ practices fulfilling multiple of our top criteria and nine practices that fulfilled all of them. These practices represent diversified crop, livestock, and forestry management including silvopasture and other agroforestry practices, wetland creation and restoration, and wildlife habitat management. The potential of these diversified, complex practices to improve multiple aspects of environmental health underscores the need for investments to prioritize transformational changes in agriculture to better support management of ongoing and future climate risks. This analysis provides evidence that there is tremendous untapped potential for conservation programs to confer greater environmental health in U.S. agriculture. This framework could provide a model for how new policies are designed and possibly in shifting or reprioritizing how current programs are implemented.

\section{DATA AVAILABILITY STATEMENT}

The complete dataset analyzed in this paper will be publicly available in the USDA Forest Service Research Data Archive, at the following url: https://doi.org/10.2737/RDS-2020-0076. 


\section{AUTHOR CONTRIBUTIONS}

AB, KT, NÁ-B, JR, LL, JM, TB, RS, and GR-M conceptualized the paper. $\mathrm{AB}, \mathrm{KT}, \mathrm{LL}, \mathrm{JM}$, and TB conceptualized the classifications. $\mathrm{AB}, \mathrm{KT}$, and $\mathrm{LL}$ categorized the practices and wrote the first draft of the paper. $A B, N A ́-B$, and JR performed the primary data analysis. LJ created the illustrations and diagrams. AB, KT, NÁ-B, JR, LL, JM, TB, RS, GR-M, and LJ edited drafts of the paper. All authors contributed to the article and approved the submitted version.

\section{FUNDING}

This work was supported by the National Socio-Environmental Synthesis Center (SESYNC) under funding received from the National Science Foundation DBI-1639145.

\section{REFERENCES}

Basche, A. (2017). Turning Soils Into Sponges: How Farmers Can Fight Floods and Droughts. Union of Concerned Scientists Report. Washington, DC. Available online at: https://www.ucsusa.org/resources/turning-soils-sponges (accessed March 24, 2020).

Basche, A. D., and DeLonge, M. S. (2019). Comparing infiltration rates in soils managed with conventional and alternative farming methods: a meta-analysis. PLoS ONE 14:9. doi: 10.1371/journal.pone.0215702

Basche, A. D., and Roesch-McNally, G. E. (2017). Research topics to scale up cover crop use: Reflections from innovative Iowa farmers. J. Soil Water Conserv. 3, 59A-63A. doi: 10.2489/jswc.72.3.59A

Bodell, J., Brandt, B., Bruner, E., Lum, P., Perez, M., and Ristow, A. (2019). Soil Health Case Studies. Washington, DC: American Farmland Trust and USDA Natural Resources Conservation Service. Available online at: https:// farmlandinfo.org/publications/soil-health-case-studies/ (accessed March 31, 2020).

Bowles, T. M., Mooshammer, M., Socolar, Y., Calderón, F., Cavigelli, M. A., Culman, S. W., et al. (2020). Long-term evidence shows that crop-rotation diversification increases agricultural resilience to adverse growing conditions in North America. One Earth 3, 284-293. doi: 10.1016/j.oneear.2020.02.007

Brandes, E., McNunn, G. S., Schulte, L. A., Bonner, I. J., Muth, D. J., Babcock, B. A., et al. (2016). Subfield profitability analysis reveals an economic case for cropland diversification. Environ. Res. Lett. 11:1. doi: 10.1088/1748-9326/11/1/014009

CRS (2018). 2018 Farm Bill Primer: What Is the Farm Bill?. Congressional Research Service. Available online at: https://crsreports.congress.gov/product/ pdf/IF/IF11126 (accessed March 24, 2020).

CRS (2019). Agricultural Conservation: A Guide to Programs. Congressional Research Service. Available online at: https://crsreports.congress.gov/product/ pdf/R/R40763 (accessed March 24, 2020).

Davis, A. S., Hill, J. D., Chase, C. A., Johanns, A. M., and Liebman, M. (2012). Increasing cropping system diversity balances productivity, profitability and environmental health. PLOS ONE 7:10. doi: 10.1371/journal.pone.0047149

DeLonge, M. S., Miles, A., and Carlisle, L. (2016). Investing in the transition to sustainable agriculture. Environ. Sci. Pol. 55: 266-273. doi: 10.1016/j.envsci.2015.09.013

Easterling, W. E. (2009). "Guidelines for adapting agriculture to climate change," in Handbook of Climate Change and Agroecosystems: Impacts, Adaptation and Mitigation, eds D. Hillel and C. Rosenzweig (Hackensack, NJ: Imperial College Press).

ESRI (2010). ArcGIS [GIS software]10.5.1. Redlands, CA: Environmental Systems Research Institute, Inc.

FAO (2011). The State of the World's Land and Water Resources for Food and Agriculture: Managing Systems at Risk. Food and Agriculture

\section{ACKNOWLEDGMENTS}

We would like to thank J. Arbuckle, Maria Bowman, Stefan Gailans, and Erich Seamon for their contributions to the broader projects underway through this SESYNC Pursuit effort. We would also like to thank Leroy Hall for his support in data acquisition and clarifying aspects of our analysis. All research at the USDA Forest Service International Institute of Tropical Forestry is done in collaboration with the University of Puerto Rico.

\section{SUPPLEMENTARY MATERIAL}

The Supplementary Material for this article can be found online at: https://www.frontiersin.org/articles/10.3389/fsufs. 2020.547876/full\#supplementary-material

Organization. Available online at: http://www.fao.org/3/i1688e/i1688e00.pdf (accessed February 1, 2020).

FAO (2018). "Agroecology can help change the world's food production for the better," in Calls for Transformative Change at 2nd International Agroecology Symposium in Rome. Food and Agriculture Organization. Available online at: http://www.fao.org/news/story/en/item/1113475/icode/ (accessed March 24, 2020).

GAO (2017). USDA's Environmental Quality Incentives Program Could Be Improved to Optimize Benefits. U.S. Government Accountability Office. Available online at: https://www.gao.gov/products/GAO-17-225?mobile_opt_ out=1 (accessed March 24, 2020).

Gliessman, S. (2014). Agroecology: The Ecology of Sustainable Food Systems, 3rd Edn. Boca Raton: Taylor \& Francis Group.

Gowda, P., Steiner, J. L., Olson, C., Boggess, M., Farrigan, T., and Grusak, M. A. (2018). "Agriculture and rural communities," in Impacts, Risks, and Adaptation in the United States: Fourth National Climate Assessment, Vol. II, eds D. R. Reidmiller, C. W. Avery, D. R. Easterling, K. E. Kunkel, K. L. M. Lewis, T. K. Maycock, et al. (Washington, DC U.S. Global Change Research Program), 391-437.

Griscom, B. W., Adams, J., Ellis, P. W., Houghton, R. A., Lomax, G., Miteva, D. A., et al. (2017). Natural climate solutions. Proc. Natl. Acad. Sci. U.S.A. 44, 11645-11650. doi: 10.1073/pnas.1710465114

Harrigan, K., and Charney, A. (2019). Impact of 2018 Farm Bill Provisions on Soil Health. National Sustainable Agriculture Coalition and Soil Health Institute Report. Available online at: https://sustainableagriculture.net/wp-content/ uploads/2019/09/FINAL-DIGITAL-Impact-of-2018-Farm-Bill-Provisionson-Soil-Health.pdf (accessed March 24, 2020).

Hatfield, J., G., Takle, R., Grotjahn, P., Holden, R. C., Izaurralde, T., et al. (2014). "Ch. 6: agriculture," in Climate Change Impacts in the United States: The Third National Climate Assessment, eds J. M. Melillo, Terese T. C. Richmond, and G. W. Yohe (Washington, DC: U.S. Global Change Research Program), 150-174.

Hatfield, J. L., Sauer, T. J., and Cruse, R. M. (2017). "Soil: the forgotten piece of the water, food, energy nexus," in Advances in Agronomy, Vol. 143, ed D. Sparks (Cambridge, MA: Academic Press), 1-46.

HLPE (2019). Agroecological and Other Innovative Approaches for Sustainable Agriculture and Food Systems That Enhance Food Security and Nutrition (HLPE Report 14). Rome: FAO, Committee on World Food Security. High Level Panel of Experts on Food Security and Nutrition. Available online at: http://www.fao. org/agroecology/database/detail/en/c/1242141/ (accessed March 24, 2020).

Janowiak, M. K., Dostie, D., Wilson, M., Kucera, M. J., Skinner, R. H., Hatfield, J. L., et al. (2016). Adaptation Resources for Agriculture: Responding to Climate Variability and Change in the Midwest and Northeast. United States Department of Agriculture Climate Hubs. Available online at: https://www.climatehubs. usda.gov/sites/default/files/AdaptationResourcesForAgriculture.pdf (accessed March 24, 2020). 
Karlen, D.L. (2012). "Soil health: the concept, its role, and strategies for monitoring," in Soil Ecology and Ecosystem Services, eds. D. H. Wall, R. D. Bardgett, V. Behan-Pelletier, J. E. Herrick, T. H. Jones, J. Six, D. R. Strong, W. H. van der Putten, and K. Ritz (Oxford: Oxford University Press), 331-336.

Karlen, D. L., Goeser, N. J., Veum, K. S., and Yost, M. A. (2017). On-farm soil health evaluations: Challenges and opportunities. J. Soil Water Conserv. 72, 26A-31A. doi: $10.2489 /$ jswc.72.2.26A

Kates, R. W., Travis, W. R., and Wilbanks, T. J. (2012). Transformational adaptation when incremental adaptations to climate change are insufficient. Proc. Natl. Acad. Sci. U.S.A. 19, 7156-7161. doi: 10.1073/pnas.1115521109

Kuepper, G. (2010). A Brief Overview of the History and Philosophy of Organic Agriculture. Available online at: https://kerrcenter.com/publication/ brief-overview-history-philosophy-organic-agriculture/ (accessed January 8, 2020).

LaCanne, C. E., and Lundgren, J. G. (2018). Regenerative agriculture: merging farming and natural resource conservation profitably. PeerJ 6:e4428. doi: $10.7717 /$ peerj. 4428

Lengnick, L. (2014). Resilient Agriculture: Cultivating Food Systems for a Changing Climate. Gabriola Island, BC: New Society Publishers.

Monast, M., Sands, L., and Grafton, A. (2018). Farm Finance and Conservation: How Stewardship Generates Value for Farmers, Lenders, Insurers and Landowners. Environmental Defense Fund Report. Available online at: https://www.edf.org/ecosystems/how-farm-conservation-can-generatefinancial-value (accessed March 24, 2020).

NFWPCAP (2012). National Fish, Wildife and Plants Climate Adaptation Strategy. Association of Fish and Wildlife Agencies, Council on Environmental Quality, Great Lakes Indian Fish and Wildife Commission, National Oceanic and Atmospheric Administration, and U.S. Fish and Wildlife Service. Washington, DC: National Fish, Wildlife and Plants Climate Adaptation Partnership. Available online at: https://www.st.nmfs.noaa.gov/ Assets/ecosystems/documents/NFWPCAS-Final.pdf (accessed September 15, 2020).

R Core Team (2020). R: A Language and Environment for Statistical Computing. Vienna: R Foundation for Statistical Computing. Available online at: http:// www.R-project.org/ (accessed March 24, 2020).

Roesch-McNally, G. E., Basche, A. D., Arbuckle, J. G., Tyndall, J. C., Miguez, F. E., Bowman, T., et al. (2018). The trouble with cover crops: Farmers' experiences with overcoming barriers to adoption. Renew. Agric. Food Syst. 4, 322-333. doi: $10.1017 /$ S1742170517000096

Rosenzweig, S. T., Fonte, S. J., and Schipanski, M. E. (2018b). Intensifying rotations increases soil carbon, fungi, and aggregation in semi-arid agroecosystems. Agric. Ecosyst. Environ. 258, 14-22. doi: 10.1016/j.agee.2018.01.016

Rosenzweig, S. T., Stromberger, M. E., and Schipanski, M. E. (2018a). Intensified dryland crop rotations support greater grain production with fewer inputs. Agric. Ecosyst. Environ. 264, 63-72. doi: 10.1016/j.agee.2018.05.017

Soil Health Institute (2018). Conference on the Connections Between Soil Health and Human Health. Available online at: https://soilhealthinstitute.org/wp-content/ uploads/2019/03/SH-HH-post-conference-report-Final-030519.pdf (accessed March 24, 2020)

Spies, T., Giesen, T., Swanson, F., Franklin, J., Lach, D., and Johnson, K. (2010). Climate change adaptation strategies for federal forests of the Pacific Northwest, USDA: Ecological, policy and socio-economic perspectives. Landsc. Ecol. 8, 1185-1199. doi: 10.1007/s10980-010-9483-0

Tully, K. L., and McAskill, C. (2020). Promoting soil health in organically managed systems: a review. Org. Agric. 10, 339-358. doi: 10.1007/s13165-019-00275-1

U.S. Congress (2019). The 116th Congress - S.2452 Climate Stewardship Act. Available online at: https://www.govtrack.us/congress/bills/116/s2452/text (accessed March, 24, 2020).

U.S. Congress (2020). The 116th Congress - H.R.5861 Agriculture Resilience Act. Available online at: https://www.congress.gov/bill/116th-congress/house-bill/ $5861 /$ text? $\mathrm{r}=91 \& s=1$ (accessed March 24, 2020).

USDA (2019). Fiscal Year 2019, Budget Summary. U.S. Department of Agriculture. Available online at: https://www.usda.gov/sites/default/files/documents/usdafy19-budget-summary.pdf (accessed March 24, 2020).

USDA (2020). Agriculture Innovation Agenda. U.S. Department of Agriculture. Available online at: https://www.usda.gov/sites/default/files/documents/ agriculture-innovation-agenda-vision-statement.pdf (accessed March 24, 2020).
USDA Forest Service (2010). National Roadmap for Responding to Climate Change. U.S. Department of Agriculture Forest Service. Available online at: https:// www.fs.fed.us/climatechange/pdf/roadmap.pdf (accessed September 15, 2020).

USDA-ERS (2019). Agricultural Resources and Environmental Indicators. U.S. Department of Agriculture Economic Research Service. Available online at: https://www.ers.usda.gov/publications/pub-details/?pubid=93025 (accessed March 24, 2020).

USDA-NASS (2020). Census Data Query Tools. U.S. Department of Agriculture National Agricultural Statistics Service. Available online at: https://www.nass. usda.gov/Quick_Stats/CDQT/chapter/1/table/1 (accessed March 24, 2020).

USDA-NRCS (2007). Interim Conservation Practice Standards. U.S. Department of Agriculture Natural Resources Conservation Service. Available online at: https://directives.sc.egov.usda.gov/OpenNonWebContent.aspx?content= 22585.wba (accessed September 17, 2019).

USDA-NRCS (2020a). Healthy Soil for Life. U.S. Department of Agriculture Natural Resources Conservation Service. Available online at: https://www.nrcs. usda.gov/wps/portal/nrcs/main/soils/health/ (accessed March 24, 2020).

USDA-NRCS (2020b). National Conservation Practice Standards. U.S. Department of Agriculture Natural Resources Conservation Service. Available online at: https://www.nrcs.usda.gov/wps/portal/nrcs/main/national/technical/cp/ncps/ (accessed March 24, 2020).

USDA-NRCS (2020c). Conservation Practice Physical Effects CPPE | NRCS Economics. U.S. Department of Agriculture Natural Resources Conservation Service. Available online at: https://www.nrcs.usda.gov/wps/portal/nrcs/detail/ national/technical/econ/tools/?cid=nrcs143_009740 (accessed March 24, 2020).

USDA-NRCS (2020d). Environmental Quality Incentives Program (EQIP). U.S. Department of Agriculture Natural Resources Conservation Service. Available online at: https://www.nrcs.usda.gov/Internet/NRCS_RCA/reports/fb08_cp_ eqip.html (accessed March 24, 2020).

USDA-NRCS (2020e). Conservation Stewardship Program (CSP). U.S. Department of Agriculture Natural Resources Conservation Service. Available online at: https://www.nrcs.usda.gov/Internet/NRCS_RCA/reports/fb08_cp_cstp.html (accessed September 2, 2020).

USDA-NRCS (2020f). Reports and Plans. U.S. Department of Agriculture Natural Resources Conservation Service. Available online at: https://www.nrcs. usda.gov/wps/portal/nrcs/main/national/about/acc/reports/ (accessed March 24, 2020).

Walthall, C. L., Anderson, C. J., Baumgard, L. H., Takle, E., Wright-Morton, L., and et al. (2013). Climate Change and Agriculture in the United States: Effects and Adaptation. Geological and Atmospheric Sciences Reports. Iowa State University. Available online at: http://lib.dr.iastate.edu/ge_at_reports/1 (accessed March 24, 2020).

Webb, N. P., Marshall, N. A., Stringer, L. C., Reed, M. S., Chappell, A., and Herrick, J. E. (2017). Land degradation and climate change: building climate resilience in agriculture. Front. Ecol. Environ. 8, 450-459. doi: 10.1002/ fee. 1530

Weisberger, D., Nichols, V., and Liebman, M. (2019). Does diversifying crop rotations suppress weeds? A meta-analysis. PLoS ONE 14:7. doi: 10.1371/journal.pone.0219847

Zimnicki, T., Boring, T., Evenson, G., Kalcic, M., and Karlen, D. L., Wilson, et al. (2020). On quantifying water quality benefits of healthy soils. BioScience 70, 343-352. doi: 10.1093/biosci/biaa011

Conflict of Interest: LL was employed by the company Cultivating Resilience, LLC.

The remaining authors declare that the research was conducted in the absence of any commercial or financial relationships that could be construed as a potential conflict of interest.

Copyright $\odot 2020$ Basche, Tully, Álvarez-Berrios, Reyes, Lengnick, Brown, Moore, Schattman, Johnson and Roesch-McNally. This is an open-access article distributed under the terms of the Creative Commons Attribution License (CC BY). The use, distribution or reproduction in other forums is permitted, provided the original author(s) and the copyright owner(s) are credited and that the original publication in this journal is cited, in accordance with accepted academic practice. No use, distribution or reproduction is permitted which does not comply with these terms. 